an enormous range of sexual behaviour, with no single version ranking as indubitably ancestral for all primates. Moreover, for a man so interested in taxonomy, Banton might learn the basic Linnaean rules. He writes, for example, that calling the herring gull by a trinomial, Larus argentatus argentatus, denotes a decision not to designate subspecies. "The species name is repeated to show that it is not divided at the subspecific level" (p. 4). Exactly the opposite is true. Repetition of the trivial name expresses a decision to divide the species into subspecies: the repeated trivial name only indicates that this particular subspecies has been designated as the 'type' or namebearer for the species.

Social context and advancing knowledge have fuelled all the transitions and backings and forthings among Banton's theories. What will happen in the future as genetic evidence indicates an astonishing similarity among 'races' (a product of the probable origin of Homo sapiens as a branching event in Africa less than 250,000 years ago, a geological yesterday) - while social divisions of first and third world continue to deepen, thus weakening the very bonds that biological knowledge is now illuminating.

Stephen Jay Gould is a Professor in the Museum of Comparative Zoology, Harvard University, Cambridge, Massachusetts 02138, USA.

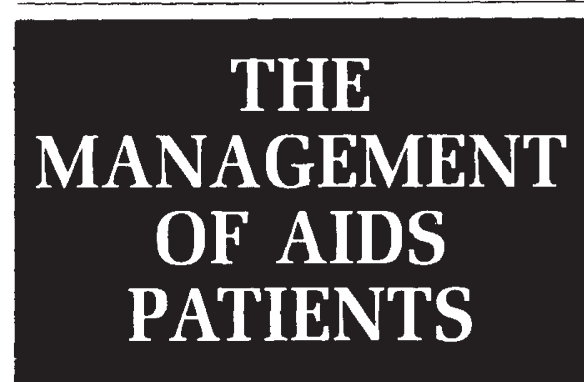

\begin{tabular}{|c|c|c|c|}
\hline \multicolumn{4}{|c|}{$\begin{array}{l}\text { Edited by DAVID MILLER, } \\
\text { JONATHAN WEBER and JOHN GREEN }\end{array}$} \\
\hline \multicolumn{4}{|c|}{$\begin{array}{l}\text { The Management of AIDS Patients is the } \\
\text { first comprehensive guide to the practical } \\
\text { clinical management of patients with AIDS } \\
\text { or HTLV III infections. The book avoids the } \\
\text { sensational aspects of the disease, offering } \\
\text { solid advice and information for all people } \\
\text { involved in patient care. }\end{array}$} \\
\hline \multicolumn{4}{|c|}{$\begin{array}{l}\text { The editors and many of the contributors } \\
\text { come from St Mary's Hospital, London one } \\
\text { of the foremost centres in Britain for the } \\
\text { treatment of AIDS patients. The knowledge } \\
\text { and experience of these experts has been } \\
\text { combined to provide a much-needed book } \\
\text { for doctors, nurses, dentists and indeed for } \\
\text { health-care professionals everywhere. }\end{array}$} \\
\hline \multicolumn{4}{|c|}{1986} \\
\hline & Hardback & 0333404653 & $£ 30.00$ \\
\hline & Paperback & 0333404661 & $£ 12.95$ \\
\hline \multicolumn{4}{|c|}{$\begin{array}{l}\text { Please order this title from your bookseller - or in case of } \\
\text { difficulty from Felicity Davie, Macmillan Press, } \\
\text { Houndmills, Basingstoke, Hants RG21 2XS. }\end{array}$} \\
\hline
\end{tabular}

\section{Jacobs' bequest}

\section{T.C. Whitmore}

The Tropical Rain Forest: A First Encounter. By Marius Jacobs. Translated and edited by Remke Kruk et al. SpringerVerlag: 1988. Pp. 295. Pbk DM64, $\$ 39.95, £ 24$.

Complete fugues could be composed from the leaves of Shorea, varying in size, thickness, venation and hairs; with countermelodies of fruits and stipules; a single fermenta for a particularly large flower; and a tremolo for an aberrant calyx. And from time to time the recurrent melody of the flowers' exquisite scent.

Shorea is a big genus of giant rain-forest timber trees. As a series of word-pictures which conjure up the majesty of tropical rain forests and the awe they inspire, Jacobs's book, from which the above quotation is taken, has few modern equals. It is written in the great tradition of nineteenth-century accounts of exploration and tropical natural history, quoting some of their more purple passages and adding some memorable new ones. It is further enhanced by the numerous magnificent illustrations, some original, many borrowed. The book was first published in 1981, in Dutch. The author died in 1983 while still translating and enlarging it. Colleagues have completed the task and added some new material.

Tropical rain forests, as everyone now knows, have been and are being hit hard. Modern machinery, rising populations, insatiable overseas markets for cheap (because undervalued) timber, the chance for politicians and businesses to become rich, all contribute. Jacobs was appalled by what he saw happening, and his book is a sustained, finely written polemic against destruction for short-term gain in the name of development. It contains some well-aimed barbs against the lack of vision of all who condone or engage in such 'development', and is by far the most eloquent and fully argued such book. The chapters on how biological knowledge has developed and is built up, and on the information we have on the New World rain forests, make excellent introductions to their subjects. That on Africa is less adequate (for example White's vegetation map and commentary are scarcely mentioned). The emphasis throughout is on the Eastern tropics with which Jacobs was best acquainted.

As its subtitle tells, the book is a 'first encounter', and as such truly conveys the flavour of the forests. But it is not successful as an ecological text. Part of the problem is that only 20 of the 400 references cited are more recent than 1981, so several newer developments are left out. Our understanding of forest mineral nutrition

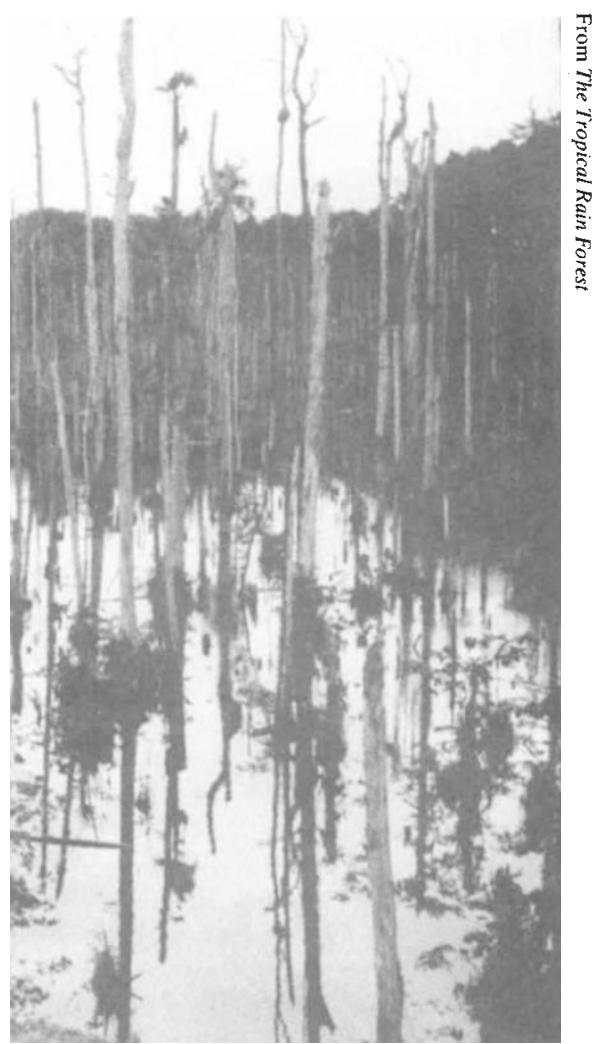

Ghost forest - where roads are constructed with inadequate drainage, local flooding kills trees (Manaus, Brazil).

is now totally different from the oldfashioned classic view expressed by Jacobs and his translators. For example, the soil below those virgin white-sand (kerangas) forests so far studied is not nutrient poor. The treatment of both macro- and microevolution and of pollination biology is heavily biased to the views of a few authors, and does not fairly reflect modern thinking on these important motors of species richness.

The other difficulty, I think, is that the painstaking, reductionist, nuts-and-bolts approach to rain-forest science which has taken us so far in recent years is not compatible with the lyrical style favoured by Jacobs. It should be possible to convey the excitement of science at the same time as conveying its details, but the book which does that for all the world's rain forests has not yet been written.

I foresee endless problems for students who read within this book simplistic glosses on biological complexity, or do not notice the many errors; for example, Kramer's gaps were $1-3 \times 10^{3} \mathrm{~m}^{2}$ not $10^{2} \mathrm{in}^{2}$ (p.91) or $1-3 \times 10^{2} \mathrm{~m}^{2}$ (p.215). Despite these blemishes this is an outstanding 'first encounter' with tropical rain forests, and a compelling plea - a cri de coeur - for the conservation of large tracts of them.

T.C. Whitmore is at the Oxford Forestry Institute, South Parks Road, Oxford OX1 3RB, UK. His own book, Tropical Rain Forests of the Far East, 2nd edn, has just been published in paperback by Oxford University Press. 